\title{
CHINESE POSTMAN PROBLEM APPROACH FOR A LARGE-SCALE CONVENTIONAL RAIL NETWORK IN TURKEY
}

\author{
Mustafa Yılmaz, Merve Kayacı Çodur, Hamid Yılmaz
}

Original scientific paper Every year, railways are inspected periodically to examine the status of rail tracks and ensure the safety of train operations of the railroad networks in Turkey. These inspection projects must be performed by several specialized machines with large and expensive equipment. Finding the optimum route of inspection machines that control through travelling all lines is critically important in terms of cost and distance. In current practice, determining the route of these machines is largerly manual and primarily relies on the knowledge and judgment of experts. This paper proposes Chinese Postman Problem (CPP) to solve the inspection machine routing problem. The objective is to minimize the total travel distance on the railroads by finding the shortest route. The proposed model is applied to a large-scale real world problem. Compared to the current practice the proposed approach significantly outperforms the reduced objective value by $20,76 \%$.

Keywords: arc routing; Chinese postman problem; railway inspection

Primjena pristupa "problem kineskog poštara" na široku mrežu turske željeznice

Izvorni znanstveni članak Svake se godine željezničke pruge periodički pregledavaju zbog ispitivanja stanja tračnica i osiguranja sigurnosti vlakova u Turskoj. Takvi se projekti moraju obaviti s nekoliko specijaliziranih lokomotiva i skupom opremom. Pronalaženje optimalnog puta takve lokomotive, vozeći na svim prugama, od bitne je važnosti zbog troškova i udaljenosti. U postojećoj praksi, određivanje rute tih lokomotiva uglavnom je manualno i oslanja se prvenstveno na znanje i procjenu stručnjaka. U ovom se radu za rješavanje problema usmjeravanja prometa inspekcijskom lokomotivom, predlaže "problem kineskog poštara" - Chinese Postman Problem (CPP). Cilj je minimizirati ukupnu prijeđenu udaljenost pronalaženjem najkraćeg pravca. Predloženi je model primijenjen na veliki problem u stvarnom svijetu. U usporedbi s postojećim stanjem predloženim se modelom smanjuje prijeđeni put za $20,76 \%$.

Ključne riječi: određivanje smjera; pregled željezničke pruge; problem kineskog poštara

\section{Introduction}

Railway infrastructure inspection is very important to ensure the safety train operations and obtain well functioning transportation systems. Every year, millions of dolars are spent on rail inspection of the railroad network in Turkey. Besides inspection costs, other costs such as train accident costs, train and shipment delay costs are also related to track inspection activities. Schlake et al. estimated that train delay costs alone can be as high as $\$ 200$ to $\$ 300$ per hour per train, and shipment or passenger delay costs can make the actual costs even much higher [1]. A comprehensive overview of the railway infrastructure inspection and maintenance field, the planning problems it contains network design, scheduling, vehicle and team routing conducted for readers interested in operational issues [2].

Track inspection includes rail inspection, tie inspection and geometry inspection, which are performed by corresponding inspection teams [3]. Rail inspection teams travel on the railroad network to identify rail defects in time by inspection machines. Several inspection activities require specialized machines with large and expensive equipment such as track and catenary measurement machines, ultrasonic inspection devices, grinding etc. [4]. It is essential that these machines are used efficiently in order to justify their high cost. Dealing with the creation of feasible routes for these inspection machines is a crucial task, since movement from one point of the network to another can take several days, even months, and this is time during which the inspection machines are not being used for inspection itself, but are just travelling. To effectively use these inspection machines on the rail network system, it is important to consider the problem of the routing inspection machines at the macro level taking into account multiple rail routes for the given origin and destination.

Studies about routing problems are separated into two categories such as node routing problems and arc routing problems. The first category focuses on network nodes whereas the second one examines the arcs. The purpose of node routing problems is to find the optimum tour in order to pass all nodes only once. The purpose of arc routing problems is to determine the shortest route or routes that lead back to beginning node by passing through all arcs present within the network at least once. The most famous examples in node routing and arc routing problems are Travelling Salesman Problem (TSP) [5] and Chinese Postman Problems (CPP). Even though CPP is similar to TSP, there are some important differences. The main difference of CPP is to be selected among arcs coupling with each others instead of one of the network nodes and this selection must occur at least once [6]. In this research, the railway inspection machine must visit all tracks (arcs) within the railway network system, so the matter at hand that routing problem is appropriate to the CPP.

The CPP was investigated by Kuan Mei-Ko, a Chinese mathematician, in 1962 [7]. As mentioned earlier, the main purpose of this problem is to determine the shortest route and to visit all arcs at least once. In a daily life, these kind of problems can be seen and mostly use many practices like delivering, road maintenance, waste or garbage collection process, electric meters reading, bus scheduling, school service scheduling, milk and newsletter delivering, police patrols and snow plow scheduling to determine these vehicles routes $[8 \div 12]$.

As mentioned above, to have an effective rail network system, it is important to find optimum routes for the inspection machine for a given origin and destination. 
Because the travel among railways imposes an important part of the total costs, problem of finding track inspection machine tour may be considered as routing problem. There are several recent studies on economic costs and benefits included to railway analysis, obtain routes and schedules that improve rail network systems [13 $\div 16]$.

Peng et al. presented Track Maintenance Scheduling Problem (TMSP) to optimize the production team in a railroad network. They used a time-space network formulation to minimize the total travel and penalty costs of the maintenance teams as well as the impact of maintenance projects [17]. In Peng and Ouyang the work is continued by introducing several more side constraints to the time-space network model and development of a better solution method [18].

Peng et al. proposed a mathematical model based vehicle routing problem formulation for Rail Inspection Scheduling Problem (RISP) where thousands of inspection tasks were scheduled subject to many constraints. The proposed modeling and solution approach applied real world case studies and showed that the proposed approach significantly outperforms the solution of the state-of-art manual procedure [19].

Lannez et al. presented rail inspection scheduling problem which consists of scheduling railway network inspection tasks. The problem is modeled as an arc routing problem to minimize the total deadhead distance while performing all inspection tasks. The inspection tasks of one year are scheduled on a sparse graph with thousand nodes and arcs assessed [20].

In literature there are several problem types such as TMSP and RISP. Both TMSP and RISP are routing and scheduling problems, where inspection or maintenance activities defined as a "task" at the network are scheduled in a horizon and assigned to a set of teams.

Because of its routing aspects, RISP is very similar to an arc routing problem where every task is represented by an arc in the network. The rail inspection machine routing problem also resembles an arc routing problem, instead of a task, every track which connects the nodes is represented by an arc in the network. Compared to rail inspection team scheduling studies, in our best knowledge, it has not been met concentrating on rail inspection machine routing problem that finding minimum tour length of machine for a given origin and destination in complex networks. Therefore, different applications have to be developed for real life problems.

In this study, CPP formulation was proposed for track inspection machine routing. The proposed approach has been applied in current Turkey railway network. The model solution was compared with the existing manuel procedure provided by experts from company, the proposed approach was able to bring significant distance savings and operational efficiency improvement.

The remaining part of the paper is organized as follows. In Section 2 problem definition for Turkey railway network is described. In section 3 , mathematical formulation based on Chinese postman problem is given. Next in section 4, the model is applied to the Turkey railway network and then the current rail inspection network in Turkey is represented by comparison with the proposed model's results. Finally, the conclusion is presented for this research.

\section{Definition of the problem}

Since 2003, the railway sector has become one of the most dynamic sectors in our country. A faster, safer and more comfortable railway operation is being carried out with the rehabilitation of a great majority of conventional lines and the renewal of rolling stock fleet. With these investments, the number of the passengers, which was 77 million in 2003, reached 153,6 million with an increase of $99 \%$ in 2014 [21].

In Turkey total conventional main line length is 8903 $\mathrm{km}$ where $8334 \mathrm{~km}$ belongs to the main lines and $569 \mathrm{~km}$ belongs to second lines. When $2369 \mathrm{~km}$ secondary lines are added to this length, our total conventional line length reaches up to $11272 \mathrm{~km} \mathrm{[21].}$

The railway lines, having an important place in transportation, create a big transportation network through old lines and also newly added lines. This big transportation network has both many advantages and many varieties of difficulties like to be routed and maintained of the trains that are circulating on lines.

In practice, all of railroad network in Turkey should be inspected periodically at a certain frequency which generally varies from once a few weeks to once a year using track measurement and inspection machines. These machines measure railway defects by rail inspection in order to ensure safety and operational efficiency of railroad networks. There are several machines having different properties that are used for the rail inspection. Some of them inspect the specific regions on a daily, weekly or monthly basis and also there are some vehicles that are used for inspecting all lines once or twice a year.

Several inspection activities require specialized teams with large and expensive equipment such as track and catenary measurement machine. So, to determine the optimum route of inspection machines that control through circulating all lines is critically important in terms of cost and distance. In order to control all network especially multi-dimensional and complex networks by the limited machines, hundreds or thousands of routes can be built up. In Turkey, there is only one vehicle that travels on all railway networks for inspection twice a year. This vehicle's name is track and catenary measurement machine. This research aims to find the optimum route of this track and catenary measurement machine by travelling on all railway network. Fig. 1 shows the Turkey railway map divided into seven regions and every region is enumerated. Taking the distance between each region in account transportation is provided among the regions. In order to solve this problem as the Chinese Postman Problem, Turkey railway map is converted to a general network $G=(V, E)$, where $V$ is the node set and $E$ is the arc set as shown in Fig. 2. A railway network is given consisting of main tracks, siding lines and junctions. In the network, there are 71 nodes and the distance between nodes is given in kilometers $(\mathrm{km})$. All arcs that connected the nodes are bidirectional and have equal distance.

In practice, schedule which consists of inspection dates, sequence of regions for inspection and machine routes is prepared by experts. 2015 year spring term inspection and measurement plans of each region are taken from Turkish Republic State Railways. Track and catenary measurement machine's current measurement plan and its route for every region are shown in Tab. 1. 
This vehicle is located in Ankara, capital city of Turkey. Therefore, the beginning point of it is in Ankara, the first node in network. After finishing the measurement process of all lines in every region, the vehicle returns back to Ankara.

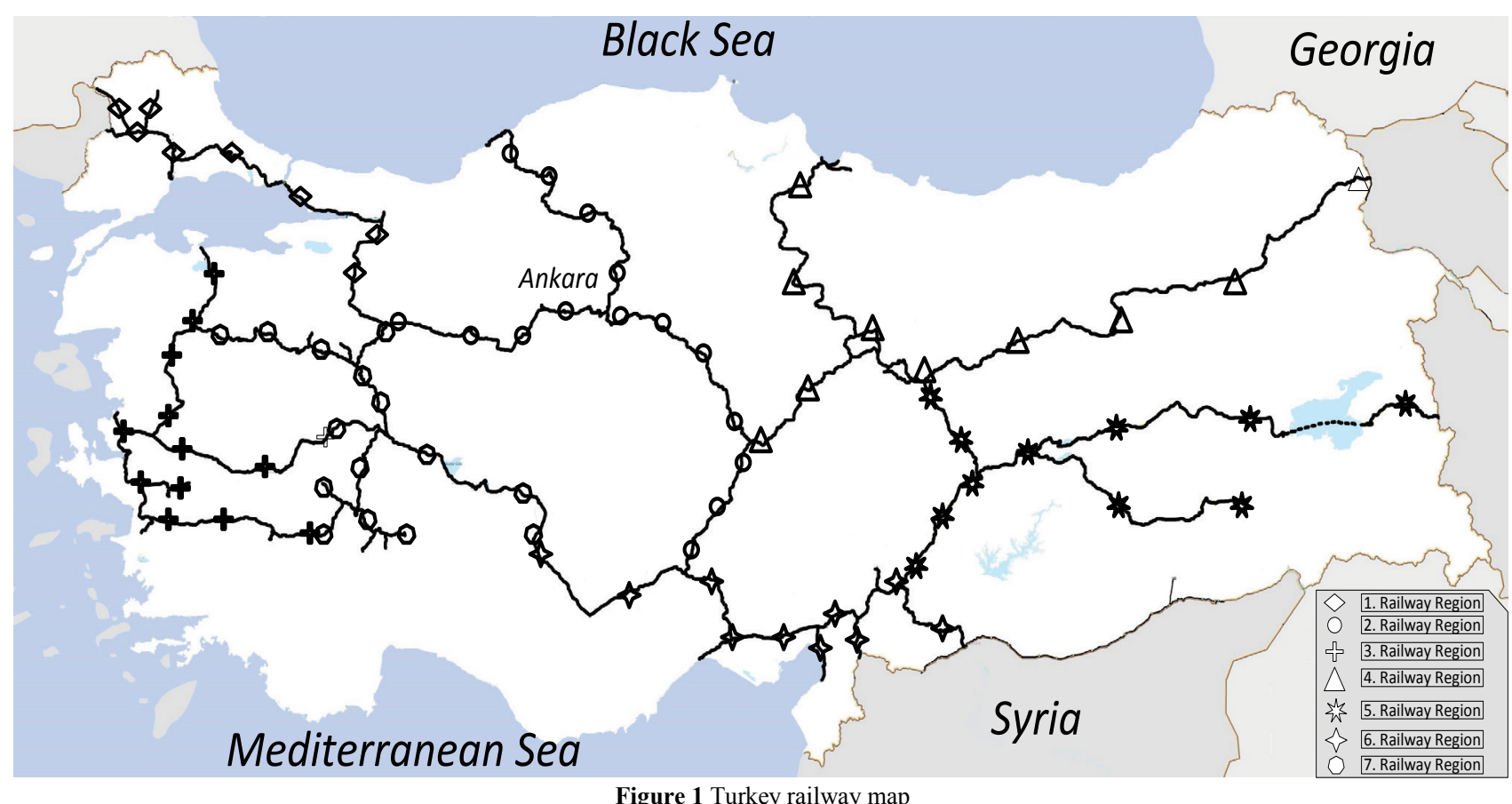

Table 1 Current route in practice of each region

\begin{tabular}{|c|c|}
\hline $\begin{array}{l}\text { Sequence of } \\
\text { regions }\end{array}$ & Existing route in practice of regions \\
\hline 1 & $1-34-35-37-38-37-39-40-39-41-43-41-42-41-39-37-35-36-35-34$ \\
\hline 3,7 & $\begin{array}{l}34-44-45-46-45-47-48-47-49-50-49-51-52-53-52-68-69-70-69-71-69-68-66-67-66-64-65-64-66-68-52-51-54-56-62-63- \\
62-64-62-56-57-58-57-59-61-59-60-59-57-56-54-55-24-55-44-34\end{array}$ \\
\hline 2 & $34-1-32-25-24-25-32-33-32-1$ \\
\hline 4 & $1-32-25-26-27-26-28-29-30-29-31-29-28-27-2-3-4-5-4$ \\
\hline 5 & $4-8-7-6-7-9-7-8-10$ \\
\hline 6 & $10-13-10-11-12-11-19-18-19-21-20-21-22-23-22-24-55-24-25-32-1$ \\
\hline
\end{tabular}

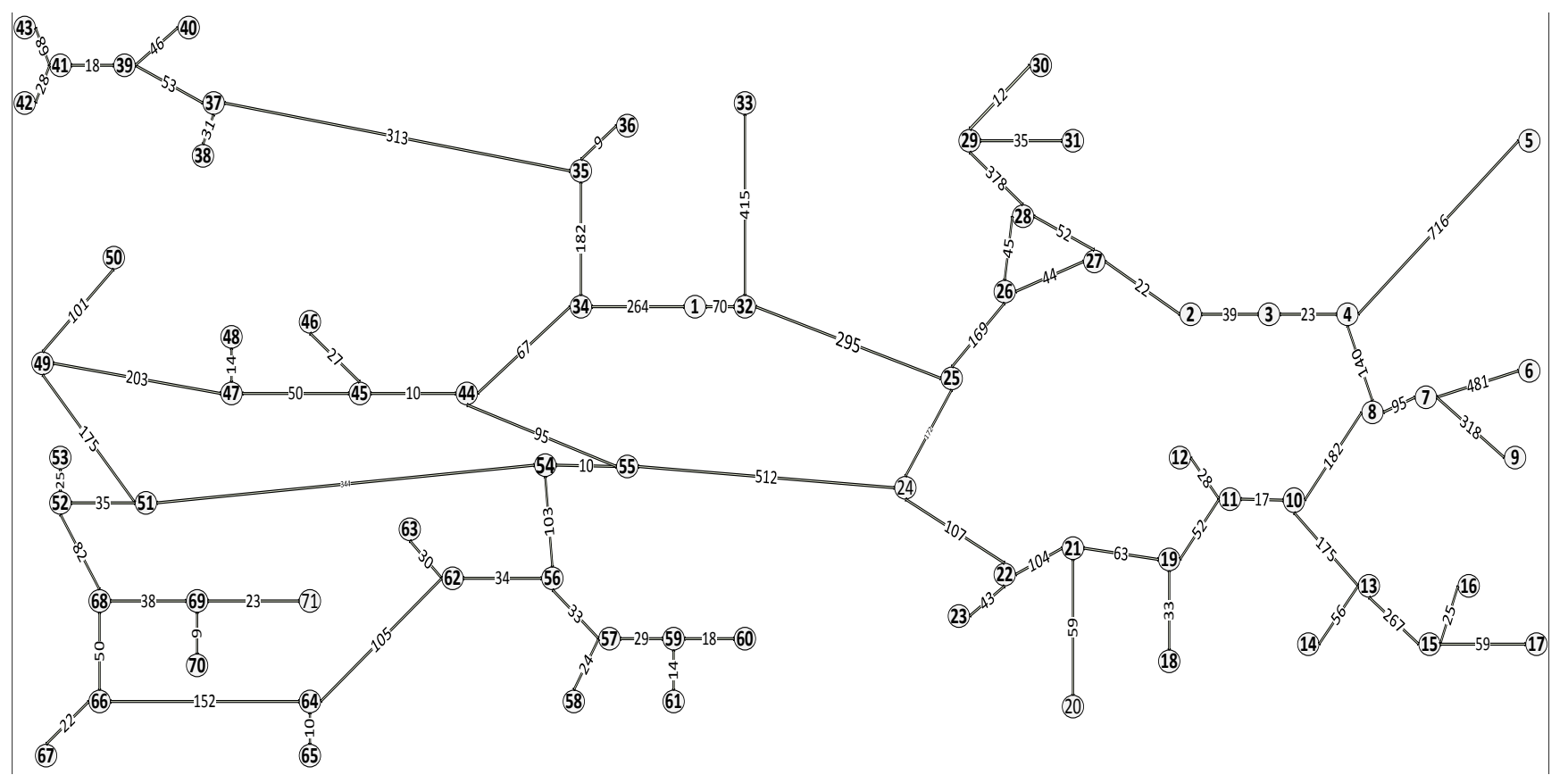

Figure 2 Graph representation of Turkey railway map

The track and catenary measurement machine starts in first region and after that performs measurement in 3-7-
2-4-5-6 respectively. This machine covers a distance of $1762 \mathrm{~km}$ in the first region. In consequence of the $3^{\text {rd }}$ and 
$7^{\text {th }}$ geographical position their route has been planned together, and is $4003 \mathrm{~km}$ totally. Second region is 2169 $\mathrm{km}, 4^{\text {th }}$ region is $3086 \mathrm{~km}, 5^{\text {th }}$ region is $2110 \mathrm{~km}$ and lastly $6^{\text {th }}$ region is $2580 \mathrm{~km}$. This machine that travels to all regions covers a distance of totally $15710 \mathrm{~km}$ and goes back to Ankara.

As mentioned above, Turkey railway map is shown as a network in Fig. 2. The problem is tested relatedly by under assumptions.

- Vehicle's fuel demand is being supplied by store management in line.

- Elapsed time in roads is ignored.

- Passenger and freight train transition, bad weather conditions are ignored and are not being added to route process.

- Some conditions of measurement machine like breakdowns are ignored.

- $\quad$ Starting point and finishing point are in Ankara.

- Even if they are shown in network, node number of $14,15,16$, and 17 are not being inspected because of the Syrian civil war and terrorism.

- Transportation over lake and Bosporus is performed by ferry and it is ignored.

\section{Chinese Postman Problem and solution procedure}

Many practical arc routing problems involve finding paths or tours that traverse a set of arcs in a graph. The aim of solving such problems is to determine the least cost tour which covers all or a subset of arcs in a graph with or without constraints [22]. The Chinese postman problem is one of the most central problems in arc routing. This problem was first solved Mei-Ko Kuan, a Chinese mathematician, in 1962 [7]. He considered this problem on the practical background of a postman picking up mail at the post office, delivering it along a set of streets, and returning to the post office. Since he must visit every street at least once, the problem is referred to as "Chinese" postman problem to investigate how to cover every street and return to the post office under the least cost. In practice, there are a lot of applications such as road maintenance, waste collection, bus scheduling, electric meters reading, snow plowing, salt gritting etc. The objective of these problems which applied the model based on CPP is to find a route so that all of the edges of a given graph have been traversed at least once within minimum cost.

The CPP is defined on an undirected graph $G=(V, E)$, where $V=\{1, \ldots, n\}$ is the set of vertices, $E=\{(i, j): i, j \in V$, $i<j\}$ is the set of undirected edges. The traversal cost $\mathrm{c}_{i j}$ of an edge $(i, j)$ in $E$ is supposed to be non-negative and is also called cost or distance of $(i, j)$. In case of an edge $(i, j)$ in $E$, it is usually assumed that $\mathrm{c}_{i j}=\mathrm{c}_{j i}$. It is generally assumed that $G$ is strongly connected that always possible to reach any vertex from any other vertex [23].

In this study, the track and catenary measurement machine is located at the beginning point. For measuring rail defects, this machine starts at the beginning point, travels along all tracks, and returns to the starting point. Since covering all tracks at least once is one of the goals, the CPP is referred to so as to investigate how to cover every track and return to the beginning point under the least cost.

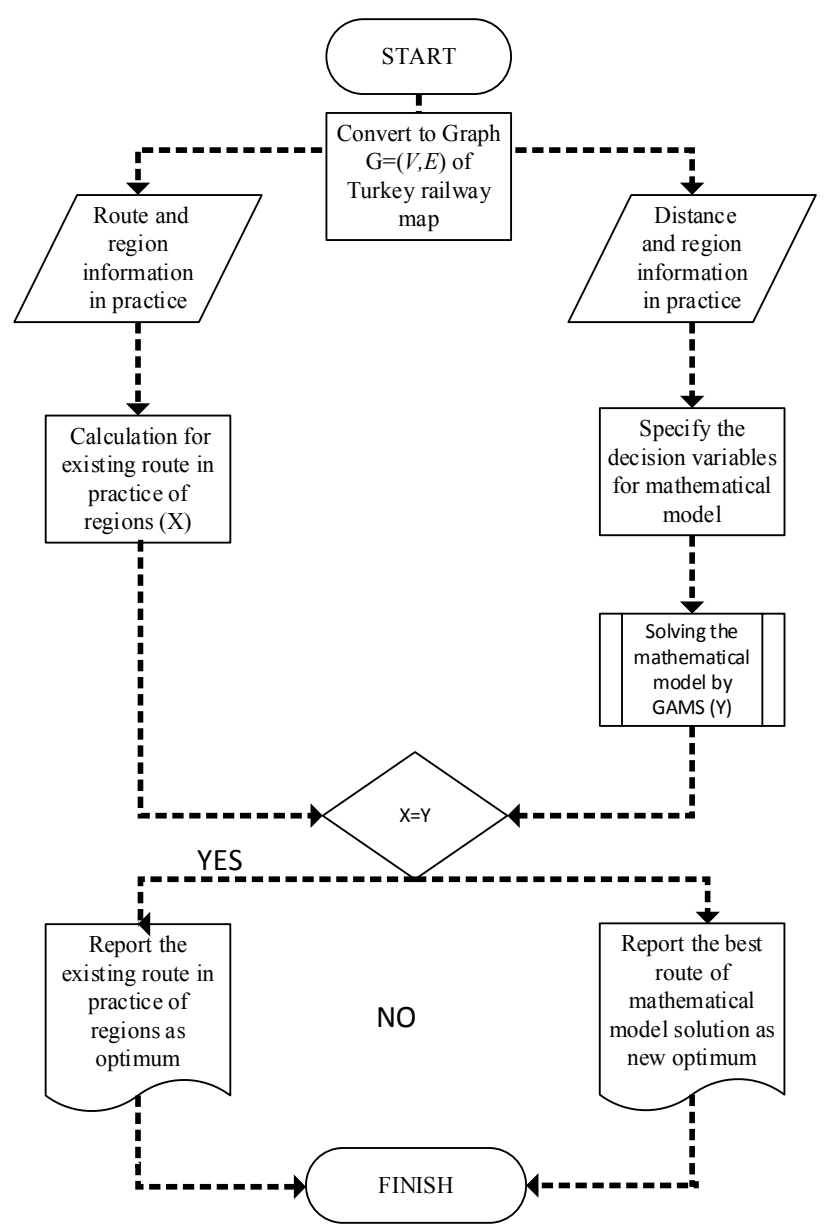

Figure 3 Flow chart of the solution procedure

As shown in Fig. 3 solution procedure is based on comparision of the solutions. One of them is the existing route and distance, the other one is searching for an optimum route. The result of existing route's total distance and the result of mathematical model is shown respectively by $X$ and $Y$. Comparison of two results is possible under equal conditions. Because if $X=Y$, it means the existing route is a perfectly scheduled route and there is no need to planning it again. If $\mathrm{X}>\mathrm{Y}$, it means the existing route is scheduled worse than optimum and a new route should be recommended for the inspeciton operations.

\subsection{Mathematical model}

The CPP mathematical model presented in this research for the Turkey railway inspection network is based on integer programming. The mathematical model is to determine an optimum route of minimum length that covers all edges of a graph at least once [6].

Finding the length of a shortest vehicle route is the main purpose of this study. For this reason, initially, the Turkey railway map is converted to a connected undirected graph $G=(V, E)$ as shown in Fig. 2. Let us consider a connected undirected graph $G=(V, E)$, with a non negative distance $c_{i j}$ for each edge $(i, j) \in E$, and a vehicle route $R$ of $G$. The value of $R$ is the sum of the distances of the edges used by $R$. To be more general, a vehicle route $R$ of a graph $G$ is a tour which contains each 
edge of the graph at least once. That is, $R=\left\{\left(v_{i}, v_{j}\right): i \in N\right.$, $j \in N,(i, j) \in E\}$.

In this study, CPP model has some assumptions including: the route is designed for a single machine. The origin for the vehicle is given and the destination for the vehicle after one cycle is the same as its origin. All arcs have the same priorities and weights. For convenience, the decision variables and parameters used in this model are summarized as shown in Tab. 2.

Table 2 Mathematical model parameters and variables

\begin{tabular}{|c|l|}
\hline \multicolumn{2}{|c|}{ Variables and parameters } \\
\hline$x_{i j}$ & $\begin{array}{l}\text { The main decision variable which represents } \\
\text { the number of times arc }(i, j) \text { is traversed in } \\
\text { each cycle using vehicle starting from node } \\
i \text { ending at node } j \text {. The variable is integer }\end{array}$ \\
\hline$x_{j i}$ & $\begin{array}{l}\text { Decision variable which represents the } \\
\text { number of times arc }(j, i) \text { is traversed in each } \\
\text { cycle using vehicle starting from node } j \\
\text { ending at node } i \text {. The variable is integer }\end{array}$ \\
\hline$C_{i j}$ & $\begin{array}{l}\text { The length for traversing arc }(i, j) \text { starting } \\
\text { from node } i, \text { ending at node } j\end{array}$ \\
\hline$V$ & Set including all nodes in the network \\
\hline$E$ & Set including all edges in the network \\
\hline$n$ & Total number of nodes in network \\
\hline
\end{tabular}

The entire formulation can be seen in the following,

$\operatorname{Min} \sum_{i=1}^{n} \sum_{j=1}^{n} C_{i j} x_{i j}$

Subject to

$$
\begin{aligned}
& \sum_{j=1}^{n} x_{i j}-\sum_{j=1}^{n} x_{j i}=0 \quad i=1,2,3, \ldots, n \quad \forall i \in V \\
& x_{i j}+x_{j i} \geq 1 \quad \forall(i, j) \in E \\
& x_{i j}, x_{j i} \geq 0 \text { and integer variables. }
\end{aligned}
$$

The objective function (1) minimizes the total length of route $\mathrm{R}$ that is covered by track inspection vehicle. Eq. (2) is flow conservation at each node constraint which guarantees the creation of a tour of the network for the vehicle. Eq. (3) ensures that each arc that exists is covered at least once during each cycle regardless of its direction using the vehicle. Eq. (4) is restriction on the variables.

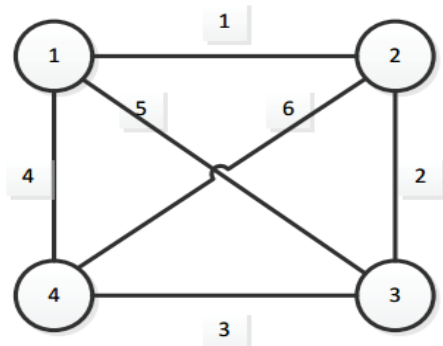

Figure 4 Example of CPP

Consider the example of Chinese postman problem as shown in Fig. 4. Given a connected undirected graph $G=(V, E)$, the vertices set is $V=\{1,2,3,4\}$, edge set is
$E=\{(1,2),(1,3),(1,4),(2,3),(2,4),(3,4)\}$. A non negative distance set is $c_{i j}=\left\{c_{12}=1, c_{13}=5, c_{14}=4, c_{23}=2, c_{24}=6, c_{34}=3\right\}$ for each edge is given on the graph.

The corresponding integer programming model of CPP is as follows:

Min $x_{12}+5 x_{13}+4 x_{14}+x_{21}+2 x_{23}+6 x_{24}+5 x_{31}+2 x_{32}+3 x_{34}+$
$4 x_{41}+6 x_{42}+3 x_{43}$

Subject to

$$
\begin{aligned}
& x_{12}+x_{13}+x_{14}-x_{21}-x_{31}-x_{41}=0 \\
& x_{21}+x_{23}+x_{24}-x_{12}-x_{32}-x_{42}=0 \\
& x_{31}+x_{32}+x_{34}-x_{13}-x_{23}-x_{43}=0 \\
& x_{41}+x_{42}+x_{43}-x_{14}-x_{24}-x_{34}=0 \\
& x_{12}+x_{21} \geq 1 \\
& x_{13}+x_{31} \geq 1 \\
& x_{14}+x_{41} \geq 1 \\
& x_{23}+x_{32} \geq 1 \\
& x_{24}+x_{42} \geq 1 \\
& x_{34}+x_{43} \geq 1 \\
& x_{i j}, x_{j i} \geq 0
\end{aligned}
$$

The objective function (5) minimizes the total length. Eq. (6), (7), (8), (9) correspond to Eq. (2) which ensures flow conservation at each node. Eq. (10), (11), (12), (13), (14), (15) correspond to Eq. (3) which ensures that each arc must be covered at least once. Eq. (16) is restriction on the variables.

The application of integer programming solvers GAMs, and the optimum of the problem are as follows:

The value of objective function $\operatorname{Min} Z=25$ and $x_{12}=1$, $x_{13}=1, x_{21}=1, x_{24}=1, x_{32}=1, x_{34}=1, x_{41}=1, x_{43}=1$. According to these variables results, each edge is traversed at least once. The optimum route obtained is $R=1-2-4-3-2$ $-1-3-4-1$. The route of vehicle/man starts at node number 1 and goes on consequentlty to $2,4,3,2,1,3,4$ and finally returns to the starting point. Total covered distance of route $R$ is 25 .

\section{Results and discussion}

In this study a CPP mathematical model is proposed that aims to find out the optimum route for track and catenary measurement machine by investigating Turkey railway current situation. This model aims to minimize total distance necessary for the maintenance of the whole railway in Turkey. To solve the problem, a computer, having Gams interface, CPlex decoder, Intel i7 3,40 GHz processor, and $8 \mathrm{~GB}$ memory is used. The results are obtained in 1,539 seconds by using 139 decision variables and 142 constraints.

Node number 1 is chosen as a starting point of the vehicle. By solving the mathematical model the best route for the vehicle is 1-32-33-32-25-24-25-26-27-26-28-2930-29-31-29-28-27-2-3-4-5-4-8-7-6-7-9-7-8-10-13-10-1112-11-19-18-19-21-20-21-22-23-22-24-55-54-56-57-5857-59-60-59-61-59-57-56-62- 63-62-64-65-64-66-67-6668-69-70-69-71-69-68-52-53-52-51-54-51-49-50-49-47- 
$48-47-45-46-45-44-55-44-34-35-36-35-37-38-37-39-40-$

39-41-42-41-43-41-39-37-35-34-1.

As shown in Tab. 3 the obtained optimum route starts at $2^{\text {nd }}$ region and visits $4^{\text {th }}, 5^{\text {th }}, 6^{\text {th }}, 3^{\text {rd }}, 7^{\text {th }}, 1^{\text {st }}$ regions respectively. When the percentage of savings of regions is considered, it is shown that the biggest improvement occurred on $6^{\text {th }}$ region and there is no improvement on $5^{\text {th }}$ region. The optimum route obtained from mathematical model's result for $2^{\text {nd }}$ region is $1539 \mathrm{~km}, 4^{\text {th }}$ region is $2720 \mathrm{~km}, 5^{\text {th }}$ region is $2110 \mathrm{~km}, 6^{\text {th }}$ region is $1019 \mathrm{~km}, 3^{\text {rd }}$ and $7^{\text {th }}$ regions are $3300 \mathrm{~km}$ and lastly $1^{\text {st }}$ region is 1760 $\mathrm{km}$. Total visited road is $12448 \mathrm{~km}$ long. According to Tab. 3, 20,76\% improvement is obtained from total distance being on line. For convenience, total traveled distances of current route and optimum route in each region are demonstrated as shown in Fig. 5.

The main reason of improvement on the optimum route is from interregional transition sequence as shown in Tab. 3. For example, in current practice, inspection starts from $1^{\text {st }}$ region, after that passes from $3^{\text {rd }}$ and $7^{\text {th }}$ regions and respectively $2^{\text {nd }}, 4^{\text {th }}, 5^{\text {th }}$ regions. Lastly, it is completed at $6^{\text {th }}$ region and goes back to the starting point. However, as shown in Tab. 3, according to the obtained optimum route, inspection starts from $2^{\text {nd }}$ region and respectively visits $4^{\text {th }}, 5^{\text {th }}, 6^{\text {th }}, 3^{\text {rd }}-7^{\text {th }}$ regions and after visiting lastly $1^{\text {st }}$ region, it goes back to the starting point.

Table 3 Optimum route results, comparison with existing route and getting improvement

\begin{tabular}{|c|c|c|c|c|}
\hline $\begin{array}{l}\text { Sequence of } \\
\text { regions }\end{array}$ & Optimum route of regions & $\begin{array}{c}\text { Total length } \\
\text { of route }(\mathrm{km})\end{array}$ & $\begin{array}{l}\text { Total length of } \\
\text { existing route in } \\
\text { practice }(\mathrm{km})\end{array}$ & $\begin{array}{c}\text { Saving } \\
(\%)\end{array}$ \\
\hline 2 & $1-32-33-32-25-24-25$ & 1539 & 2169 & 29,04 \\
\hline 4 & $25-26-27-26-28-29-30-29-31-29-28-27-2-3-4-5-4$ & 2720 & 3086 & 11,86 \\
\hline 5 & $4-8-7-6-7-9-7-8-10$ & 2110 & 2110 & 0,0 \\
\hline 6 & $10-13-10-11-12-11-19-18-19-21-20-21-22-23-22-24$ & 1019 & 2580 & 60,50 \\
\hline 3,7 & $\begin{array}{l}24-55-54-56-57-58-57-59-60-59-61-59-57-56-62-63-62-64-65-64-66- \\
67-66-68-69-70-69-71-69-68-52-53-52-51-54-51-49-50-49-47-48-47- \\
45-46-45-44-55-44-34\end{array}$ & 3300 & 4003 & 17,56 \\
\hline 1 & $34-35-36-35-37-38-37-39-40-39-41-42-41-43-41-39-37-35-34-1$ & 1760 & 1762 & 0,11 \\
\hline Total length & & 12448 & 15710 & 20,76 \\
\hline
\end{tabular}

A vehicle that follows this optimum route goes from one node to others only once and finishes whole network without doing any repetition. For example, in Tab. 1, transition from $24^{\text {th }}$ node to $55^{\text {th }}$ node is repeated both at number of $3^{\text {rd }}, 7^{\text {th }}$ regions and number $6^{\text {th }}$ region's inspection. However, in the proposed optimum route, the road between these nodes has been used only once. So, the result shows that real life practice is different from both interregional transition sequences and there is no repetition of transition between network's points. In terms of these two situations, it shows the optimum result.

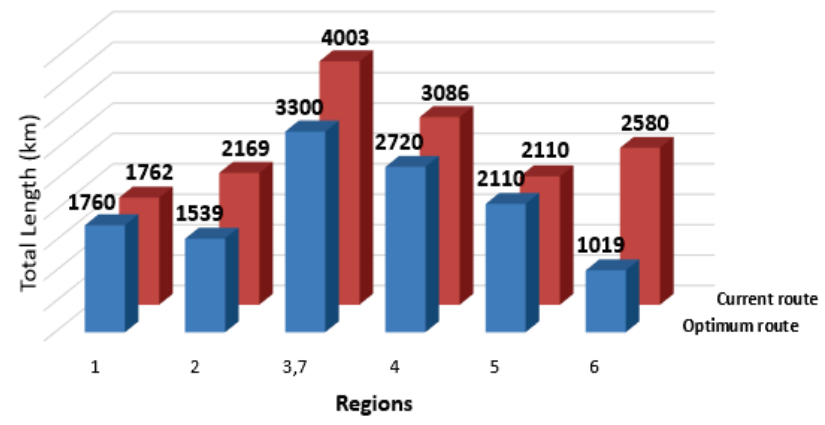

Figure 5 Covered distances of regions

\section{Conclusion}

Routing is an important process for several production and service sectors. States and entrepreneurs spend millions of dollars for these operations every year. Besides, sizeable amount of money has been spent because of wrong planning. In this regard, studies have an important role in terms of cost.

In this study, an inspection vehicle used for Turkey railway is investigated for determining the shortest route on the nondirectional railroads. It is solved by Chinese postman problem which is one of the arc routing problems. In this research, the presented Turkey railway inspection plans are compared with the proposed optimum inspection plan. According to this research results, in practice, the vehicle circles the network by visiting roads many times, but the circle is completed by visiting the optimum route only once. In this way, needless repetition problem has been solved, so total covered distance by machine became shorter.

This research opens some other avenues for future research. Under some hypothesis like whether to have only one inspection machine with limited capacity or to do transition by giving priorities to some routes, the problems can be solved by thinking about or redefining them again. As mentioned before, since the problem is large scale and complex, finding the optimum route within thousands of alternative routes will be difficult. For this reason, if mathematical model does not respond to bigger and more complex network structures, some heuristic methods that produce feasible solution can be developed.

\section{References}

[1] Schlake, B. W.; Edwards, J. R.; Hart, J. M.; Barkan, C. P. L; Todorovic, S.; Ahuja, N. Automated Inspection of Railcar Underbody Structural Components Using Machine Vision Technology. // In Proceedings of the TRB 88th Annual Meeting / Washington, DC, 2009, pp. 01-17.

[2] Liden, T. Railway Infrastructure Maintenance - ASurvey of Planning Problems and Conducted Research. // Transportation Research Procedia. 10, (2015), pp. 574583. https://doi.org/10.1016/j.trpro.2015.09.011

[3] Peng, F. Scheduling of Track Inspection and Maintenance Activities in Railroad Networks (PhD Thesis). // University of Illinois at Urbana-Champaign, Urbana, Illinois, 2011. 
[4] Cannon, D. F.; Edel, K. O.; Grassie, S. L.; Sawley, K. Rail Defects: An Overview. // Fracture \& Fatigue of Engineering Material \& Structures. 26, 10(2003), pp. 865886. https://doi.org/10.1046/j.1460-2695.2003.00693.x

[5] Laporte, G. The Traveling Salesman Problem: An Overview of Exact and Approximate Algorithms. // European Journal of Operational Research. 59, 2(1992), pp. 231-247. https://doi.org/10.1016/0377-2217(92)90138-Y

[6] Eiselt, H. A.; Gendreau, M.; Laporte, G. Arc Routing Problems, Part-1: The Chinese postman problem. // Operations Research. 43, (1995), pp. 231-242. https://doi.org/10.1287/opre.43.2.231

[7] Kuan, M. K. Graphic Programming Using Odd or Even Points. // Chinese Mathematics. 1962, pp. 237-277.

[8] Eglese, R. W.; Li, Y. L. O. An Interactive Algorithm for Vehicle Routing for Winter-gritting. // The Journal of Operational Research Society. 47, 2(1996), pp. 217-228.

[9] Laporte, G. Modeling and Solving Several Classes of Arc Routing Problems as Traveling Salesman Problems. // Computers \& Operations Research. 24, 11(1997), pp. 1057-1061. https://doi.org/10.1016/S0305-0548(97)00013-0

[10] Assad, A. A.; Golden, B. L. Arc Routing Methods and Applications. // In network routing / Handbooks in Operations Research and Management Science, 1995. pp. 375-483.

[11] Shafahi, A.; Haghani, A. Generalized Maximum Benefit Multiple Chinese Postman Problem. // Transportation Research Part C: Emerging Technologies. 55, 2015, pp. 261-272. https://doi.org/10.1016/j.trc.2015.01.017

[12] Lemieux, P. F.; Campagna, L. The Snow Ploughing Problem solved by a Graph Theory Algorithm. // Civil Engineering Systems, 1, 6(1984), pp. 337-341. https://doi.org/10.1080/02630258408970368

[13] Gašparík, J.; Abramović, B.; Halás, M. New Graphical Approach to Railway Infrastructure Capacity Analysis. // PROMET - Traffic \& Transportation. 27, 4(2015), pp. 283-290. https://doi.org/10.7307/ptt.v27i4.1701

[14] Murali, P.; Ordó-ez, F.; Dessouky, M. M. Modelling Strategies for Effectively Routing Freight Trains through Complex Networks. // Transportation Research Part C: Emerging Technologies. 70, (2016), pp. 197-213. https://doi.org/10.1016/j.trc.2015.08.022

[15] Fu, H.; Nie, L.; Meng, L.; Sperry, B. R.; He, Z. A Hierarchical Line Planning Approach for a Large-scale High Speed Rail Network: The China Case. // Transportation Research Part A. 75, (2015), pp. 61-83. https://doi.org/10.1016/j.tra.2015.03.013

[16] Hong, S. P.; Kim, K. M.; Lee, K.; Park, B. H. A Pragmatic Algorithm for the Train-Set Routing: The Case of Korea High-speed Railway. // The International Journal of Management Science. 37, 3(2009), pp. 637-645. https://doi.org/10.1016/j.omega.2008.03.003

[17] Peng, F.; Kang, S.; Li, X.; Ouyang, Y.; Somani, K.; Acharya, D. A Heuristic Approach to the Railroad Track Maintenance Scheduling Problem. // Computer-Aided Civil and Infrastructure Engineering. 26, 2(2011), pp. 129145. https://doi.org/10.1111/j.1467-8667.2010.00670.x

[18] Peng, F.; Ouyang, Y. Track Maintenance Production Team Scheduling in Railroad Networks. // Transportation Research Part B: Methodological. 46, 10(2012), pp. 14741488. https://doi.org/10.1016/j.trb.2012.07.004

[19] Peng, F.; Ouyang, Y.; Somani, K. Optimal Routing and Scheduling of Periodic Inspections in Large-scale Railroad Networks. // Journal of Rail Transport Planning \& Management. 3, 2013, pp. 163-171. https://doi.org/10.1016/j.jtpm.2014.02.003

[20] Lannez, S.; Artigues, C.; Damay, J.; Gendreau, M. A Railroad Maintenance Problem Solved With a Cut and Column Generation Matheuristic. // Networks, Wiley. 66, 1(2015), pp. 40-56. https://doi.org/10.1002/net.21605
[21] Turkey, Republic of Turkey General Directorate of Turkish State Railways Annual Report. 2014. http://www.tcdd.gov.tr/files/istatistik/2012faaliyetraporu.pdf (01.12.2015)

[22] Corberan, A.; Laporte, G. Arc Routing Problems, Methods, and Applications. Society for Industrial and Applied Mathematics, USA, 2014.

[23] Dror, M. Arc Routing: Theory, Solutions and Applications. Springer Science+Business Media, Newyork, 2000.

\section{Authors' addresses}

Mustafa Yılmaz, Assist. Prof.

Faculty of Industrial Engineering

University of Atatürk

25070 Erzurum, Turkey

E-mail: mustafay@atauni.edu.tr

Merve Kayacı Çodur, Research Assistant (PhD)

Faculty of Industrial Engineering

University of Atatürk

25070 Erzurum, Turkey

E-mail:mkayaci@atauni.edu.tr

Hamid Yulmaz, Research Assistant (PhD)

Bayburt University, Industrial Engineering Department, Dede Korkut Kampüsü, 69000 Bayburt, Turkey

E-mail: hamidyilmaz@bayburt.edu.tr 